\title{
Rural Public Expenditure and Poverty Alleviation in China: A Spatial Econometric Analysis
}

\author{
Weilin Liu ${ }^{1}$, Jingdong $\mathrm{Li}^{2} \&$ Rong $\mathrm{Zhao}^{3}$ \\ ${ }^{1}$ Postdoctoral Research Workstation, Chinese Academy of Science and Technology for Development, Beijing, \\ China \\ ${ }^{2}$ Institute of Geographical Sciences and Natural Resources Research, Chinese Academy of Sciences, Beijing, \\ China \\ ${ }^{3}$ Research Institute of Forestry Policy and Information, Chinese Academy of Forestry, Beijing, China \\ Correspondence: Rong Zhao, Research Institute of Forestry Policy and Information, Chinese Academy of \\ Forestry, No.1 Dong Xiao Fu, Xiang Shan Road, Beijing, 100091, China. Tel: 189-1196-0990. E-mail: \\ 460326029@qq.com
}

Received: March 7, 2020

Accepted: April 12, $2020 \quad$ Online Published: May 15, 2020

doi:10.5539/jas.v12n6p46

URL: https://doi.org/10.5539/jas.v12n6p46

The research is financed by the National Forestry and Grassland Bureau Major Research Project-Study on the Performance Evaluation of Forestry Ecological Poverty Alleviation and Long-term Mechanism (JYC2019-62).

\begin{abstract}
In China, one of the most important reducing poverty means is continuous and large-scale public financial investment. This paper investigated the structural differences between rural public expenditure (namely, education, health, social security, infrastructure, living environment) and poverty in 27 provinces of China in 2010-2016 from the spatial econometric perspective. The results showed the structural differences in poverty reduction effects of government spending are very obvious, indicating that expenditures on education, health care, social security and infrastructure have all shown good poverty alleviation effects, while living environment spending has no significant effect on poverty reduction. We further find that government spending not only promote poverty reduction in the region, but also reduce poverty in economically and geographically similar areas, which suggests that future work should look more closely at whether and how the effect of government spending on poverty varies by structure. Thus, the findings established in this paper have significant implications for targeted poverty alleviation measures in China through government spending policies.
\end{abstract}

Keywords: government spending, poverty reduction, spatial autocorrelation, spatial regression

\section{Introduction}

In December 2019, the "China Human Development Report 2019" issued by the United Nations Development Program, targeted poverty alleviation is an important experience in poverty reduction in China, and this "Chinese experience" is an important reference for global poverty reduction efforts. Official Chinese data show that the corresponding percent of the population living in rural poverty decreased from $97.5 \%$ in 1978 to $0.6 \%$ in 2019 (2010's standard) (NBS, 2020). Even so, there were still around 5.51 million rural people in poverty at that time. The government aims to lift all the remaining extremely poor rural population above the current poverty standard by 2020. Recent research indicates that this target is unlikely to be met by economic growth alone. Meeting the targeted poverty alleviation target requires not just growth, but growth that is combined with resource distributional changes that by themselves reduce poverty (Anderson et al., 2018).

There has been much debate in the literature about the factors that affect the amount of poverty reduction (e.g., Verschoor \& Kalwij, 2006; Son \& Kakwani, 2008). Within this debate, government expenditure is often argued to be one key influence (Anderson et al., 2018). In China, the government is the main subject of poverty reduction, and has played a very important leading role in poverty reduction, forming a fruitful government-led poverty reduction model. From 2016 to 2019, the central government has allocated 384.38 billion yuan in special poverty alleviation funds, an average annual increase of $28.6 \%$. The "Guiding Opinions on Winning Three Years of Action to Fight Poverty Alleviation", in 2016, proposes to increase financial support for special poverty 
alleviation funds and transfer payments such as education and health, and insist on increasing government investment in poverty alleviation and improving the efficiency of fund use. Therefore, public fiscal poverty alleviation has become one of the most commonly used methods of the Chinese government to reduce poverty (Wang \& Liu, 2016).

Several studies have investigated the relationship between public spending and rural poverty, and show an interesting diversity of results. Some researchers maintain that public expenditure is an effective instrument in achieving poverty reduction goals (Fan, 2002; Sergiy, 2006; Lal \& Sharma, 2009; Duan, 2018). The experience of some developed and developing countries in the world shows that government expenditure can effectively increase the income level of the poor and thus alleviate poverty (Gittell, 2010). In developed countries, public welfare expenditures and education expenditures implemented in United States, social security and welfare expenditures implemented in United Kingdom, and Danish central and local welfare fiscal systems have all produced good results. OPEC member countries should invest more on the quality of human capital through education and health to improve the living standard of people and social welfare (Olopade et al., 2018). In developing countries, fiscal expenditure policies such as rural private transfer payment schemes and employment security schemes implemented in India can effectively alleviate poverty (Gaiha \& Imai, 2002; Lal \& Sharma, 2009). Non-food subsidies in the Philippines have better poverty alleviation effects than food subsidies (Conchada \& Rivera, 2013). Brazil's implementation of "development pole measures" using public policy has also significantly reduced poverty. In contrast, some scholars think that the objective of sound public finance seems to be gained at the expense of a higher number of people living in poverty, and a large part of government spending does not reach poor households, due to imperfect targeting (Easterly \& Fischer, 2001; Lindert et al., 2006; Anderson, 2018; Canale et al., 2019). A literature review by Chu et al. (2000) covering 55 developing country studies, for example, finds that while public spending in education and health are progressive (i.e., equalizing), they were not sufficiently targeted to the poor especially in sub-Saharan Africa. Similarly, Transfer payments and society security can also have side effects, e.g., on household labor supply, or on receipts of private transfers, which can offset their effect on rural poverty (e.g., Sahn \& Alderman, 1996; Cox et al., 2004). Thus even when well targeted, the overall impact of public expenditure on poverty is ambiguous.

Different types of rural public expenditure have different effects on rural poverty, according to the sector of spending, how well it is targeted, and the way in which it is financed. The effect may also differ according to poverty reduction path, since some types of spending have direct impacts on poverty (e.g., society security), while others only have more indirect effects (e.g., health, education, infrastructure and living environment) (Wang \& Liu, 2016; Anderson, 2018). From the perspective of individual public sector impacts on poverty reduction, rural infrastructure investment (Fan et al., 2005; Yu et al., 2011), rural society security (Benjamin et al., 2005), and health and education expenditures (Gomanee \& Morrissey, 2002; Oluwatobi \& Ogunrinola, 2011; Kruse et al., 2012) are effective means to achieve poverty reduction. Asadullah et al. (2014) found that fiscal expenditure on education did not have a significant poverty reduction effect, while health care had a significant poverty reduction effect in Bangladesh. Asghar et al. $(2011,2012)$ found that spending on human capital and community service has a positive correlation with economic growth, while spending on education, health and law and order has a negative correlation with the poverty rate in Pakistan. In addition, other sources of spending which were highlighted by the study as sources that did not help to either boost economic growth or reduce poverty, were spending on subsidies and society security. These studies may partly explain the structural differences in poverty reduction effects of rural public spending.

This paper investigates the effect of rural public expenditure on poverty in 27 provinces of rural China in 2010-2016. In the Chinese case, some scholars analyze in detail the impact and priorities of public expenditure structure on agricultural growth and poverty reduction (e.g., Fan et al., 2005, 2007). When researching the effect of public expenditure on poverty reduction, it is unavoidable to consider whether the poverty reduction effect of public expenditure has spatial correlation, which is determined by the spatial distribution of public expenditure (Gong et al., 2018). Theoretically, since government spending must be distributed among different regions, its poverty reduction effect will necessarily involve issues such as whether there is space spillover or spatial difference. There is some evidence for the effects of single government sector spending on rural poverty from a spatial econometric perspective (Zou, 2014; Deng et al., 2015). Also, few among others include the study by Gong et al. (2018) focused on the rural public spending. Thus, this study not only takes into account structural differences between rural public expenditure and poverty for China's rural regions, but also distinguish between the direct and indirect impacts of rural public expenditure on rural poverty. This paper is organized as follows. The second section will explain the research method and then the empirical research will be discussed. The final section compromises the concluding remarks and policy implications. It is believed that this study will give 
insight on how rural public spending resource allocation can be used to accelerate growth, increase income per capita and reduce poverty in China.

\section{Methods and Data}

\subsection{Spatial Econometric Model}

Spatial statistical methods, including spatial statistical analysis models, can be used to reveal the spatial characteristics of a dataset by reflecting the mean difference between a range of spatial units and their adjacent units (Anselin, 1993).

$$
\text { Moran's } I=\frac{\sum_{i=1}^{n} \sum_{j=1}^{n} W_{i j}\left(Y_{i}-\bar{Y}\right)\left(Y_{j}-\bar{Y}\right)}{S^{2} \sum_{i=1}^{\mathrm{n}} \sum_{j=1}^{n} W_{i j}}
$$

where, $S^{2}=\frac{1}{\mathrm{n}} \sum_{i=1}^{n}\left(Y_{i}-\bar{Y}\right), \bar{Y}=\frac{1}{\mathrm{n}} \sum_{i=1}^{n} Y_{i}, Y_{i}$ is the value of province $\mathrm{i}$, and $\mathrm{n}$ is the number of provinces. $W$ represents the spatial weights matrix, which is a key issue in spatial econometrics. We will measure public spending and poverty with a mixed geography-economy weighting matrix $(W)$, that combines the geographic distance weighting matrix $\left(W_{1}\right)$ and economy weighting matrix $\left(W_{2}\right)$ in view of the robustness of research results. The specific formula of geographical distance weight matrix is as follows:

$$
W_{1}= \begin{cases}\frac{1}{D_{\mathrm{ij}}^{2}} & i \neq j \\ 0 & i=j\end{cases}
$$

$\mathrm{D}_{\mathrm{ij}}$ is the geographical distance between province $\mathrm{i}$ and province $\mathrm{j}$ calculated with the latitude and longitude data of the prefecture-level province's administrative unit. The specific measure formula is as follows:

$$
D_{\mathrm{ij}}=R \times \arccos \left(\sin \phi_{A} \sin \phi_{B}+\cos \phi_{A} \cos \phi_{B} \cos \left(\lambda_{B}-\lambda_{A}\right)\right)
$$

$R$ is the earth circle radius $(6378 \mathrm{~km}) ; \lambda$ and $\varphi$, respectively, represent the longitude and latitude of the administrative centers for province $\mathrm{i}$ and province $\mathrm{j}$. Longitude and latitude data are from the national fundamental geographic information system.

$W_{2}$ is the economic weights matrix. The specific formula for measurement is as follows:

$$
W_{2}= \begin{cases}\frac{1}{\left|G D P_{\mathrm{i}}-G D P_{j}\right|} & i \neq j \\ 0 & i=j\end{cases}
$$

where, $G D P_{i}$ and $G D P_{j}$ represent the per capita actual GDP of province i and province j, respectively.

The mixed spatial weights matrix $(W)$ is the economic-geographical weights matrix. In order to comprehensively reflect the spatial effects of geographical and economic characteristics, we will construct a mixed geography-economy weighting matrix. The specific measure is as follows:

$$
W= \begin{cases}W_{1} \times W_{2} & i \neq j \\ 0 & i=j\end{cases}
$$

To analyze the spatial effects of rural public expenditure on poverty, in this study, we employed spatial panel regression models. Rural poverty is affected by the economic development of not only the focal province, but also the surrounding area. Poverty thus has strong spatial autocorrelation (Ravallion, 2012). Thus, an approach based on spatial econometric modeling was adopted in this study. In general, there are two major spatial econometric models, namely, the spatial autoregressive (SAR) model and the spatial error (SEM) model.

The SAR model can be expressed by,

$$
P O V_{\mathrm{it}}=\alpha_{i}+\rho W P O V_{\mathrm{it}}+X_{i t} \theta+\varepsilon_{i t}
$$

where, $P O V_{i t}$ represents rural poverty rate, $W$ is the spatial weights matrix, $\rho$ is the spatial autoregressive coefficient, $X_{i t}$ is the vector comprising the explanatory variable, $\theta$ is the coefficient of the explanatory variables, and $\varepsilon_{i t}$ is the random error.

The SEM model mainly addresses the spatial dependence presented in the error term (Elhorst, 2003). It is expressed by:

$$
P O V_{\mathrm{it}}=\alpha_{i}+X_{i t} \theta+\mu_{i t}, \mu_{i t}=\beta W \mu_{i t}+\varepsilon_{i t}
$$


where, $\beta$ is the spatial autoregressive coefficient, and $P O V_{i t}, W, X_{i t}, \theta$, and $\varepsilon_{i t}$ have the same meaning as in Equation (7).

\subsection{Selection of Variables and Data Sources}

\subsubsection{Rural Poverty and Poverty Alleviation}

Reducing poverty is a major tenet of the government's current push to improve social welfare. Commonly, poverty is represented by the poverty rate - the percentage of population at or below the poverty line. In China, the standard poverty line was defined as an annual per capita net income in rural areas of 2,300 Yuan (at the 2010 constant price) based on the China Rural Poverty Alleviation and Development Program (2011-2020). Considering the coherence and availability of data, this article finally selected the poverty rate (2010 standard) in the "China Rural Poverty Monitoring Report" from 2010 to 2016 as a variable to measure rural poverty. In general, a higher poverty ratio implies more impoverished conditions (Wardhana et al., 2017; Westmore, 2018; Inoue, 2018; Harrison et al., 2019).

\subsubsection{Selection of Variables for Rural Public Expenditures}

China is a typical government-led country, and the government is the main public service provider. According to the research purpose and related literature (Liu \& Lin, 2014; Tang, 2016), public expenditure data of rural livelihood security were selected as indicators of the level of investment in rural public services, and use the panel data of 27 provinces and territories of China (excluding Beijing, Tianjin, Shanghai (Note 1), Tibet, Hong Kong, Macao, and Taiwan) for the period 2010-2016. In order to eliminate the impact of population size and price fluctuations, specific indicators use "per capita public expenditure", that is, the indicator data is averaged according to the number of rural populations in the corresponding province and year, and deflated in line with GDP index for 2007. Based on China's poverty alleviation policy, rural public service planning, and existing research literature (Zeng, 2013; Zuo et al., 2018; Lustig, 2019), we chose five dimensions, rural education expenditure (EDE), rural health expenditure (HEE), rural social security expenditure (SOE), rural infrastructure expenditure (INFE), rural living environment expenditure (ENVE), as the key core variables for measuring rural public expenditure. Since various public expenditures in rural areas cannot be directly obtained, the corresponding technical processing of statistical data is carried out as follows:

(1) Rural Education Expenditure (EDE): Based on the "Implementation plan to tackle poverty in education in deeply impoverished areas (2018-2020)", which was proposed to consolidate rural compulsory education and popularize rural senior secondary education, we chose primary education spending, junior secondary education spending, and senior secondary education spending, as the key rural public education expenditure data from the China Educational Finance Statistical Yearbook. The above three indicators have a strong correlation, so the principal component analysis method is used to compress the variables, and the principal component score is used as an indicator of rural public education investment.

(2) Rural Health Expenditure (HEE): According to Liu and Zhang (2011) calculation methods, the annual national urban and rural per capita health expenditures were obtained from the China Health Statistics Yearbook, and the ratio of the total urban and rural per capita health expenditures was taken as the ratio of urban and rural per capita health financial expenditures in each province. Taking 2013 as an example, the per capita health expenditure in urban areas was 3558.31 yuan, and the per capita health expenditure in rural areas was 1142.21 yuan. If the per capita health expenditure in rural areas in each province is set to $\mathrm{x}$, then the per capita financial expenditure on health in cities in each province is 3558.31 divided by 1412.21 , multiplying by $\mathrm{x}$ and the number of urban and rural populations in each province, and then summing them up should be equal to the health fiscal expenditure of each province, so as to obtain the rural health expenditure per capita in each province.

(3) Rural Social Security Expenditure (SOE): According to the connotation of rural social security in China, it mainly includes four aspects: rural pension insurance, rural medical insurance, rural social assistance, and rural social welfare (Qiu \& Wen, 2012). The total cost of rural social services is selected from the China Civil Affairs' Statistical Yearbook. Expenditures replace total rural social relief and social welfare expenditures. The rural pension insurance fiscal expenditure is replaced by the product of the basic pension and the corresponding number of participants. The financial expenditure for rural medical insurance is the product of the government subsidy standard for the urban and rural basic medical insurance (NRCMS) and the corresponding number of participants in each region. The above expenditures are aggregated into rural social security fiscal expenditures, and then divided by the rural population in each region, that is, the rural social security input indicators.

(4) Rural Infrastructure Expenditure (INFE): Refer to the China Rural Statistical Yearbook and related literatures (Liu \& Lin, 2014; Tang, 2016; Leng et al., 2016), this paper uses expenditure for agriculture, forestry and water 
conservancy are comprehensively substituted for data on rural water conservancy facilities, power facilities, energy facilities, and communication facilities, and then divided by the rural population in each area, which is the index for rural infrastructure expenditure.

(5) Rural Living Environment Expenditure (ENVE): Refer to the Urban and Rural Construction Statistical Yearbook 2010-2016, this paper selects housing construction investment, drainage and sewage treatment construction investment, landscaping investment, environmental sanitation investment as living environment indicators. In addition, the village planning and remediation investment is not listed separately, so other investment in village construction investment is selected to replace it. After the above-mentioned construction investment is aggregated, it is divided by the sum of the household registration population and the temporary population (Note 2 ) in each province to obtain the rural per capita living environment investment index.

\subsubsection{Selection of Controlled Variables}

In addition to public expenditure and rural poverty is affected by other factors. The description and measurement of these variables are shown in Table 1 .

Table 1. Description of control variables

\begin{tabular}{|c|c|c|c|}
\hline Abbr & Description & Measurement & Notes \\
\hline PGDP & $\begin{array}{l}\text { Gross domestic } \\
\text { product per capita }\end{array}$ & Regional real GDP per capita (constant 2007 RMB yuan) & $\begin{array}{l}\text { PGDP is used to measure the regional } \\
\text { economic development. }\end{array}$ \\
\hline URB & Urbanization rate & The percentage of the total city population living in urban areas. & $\begin{array}{l}\text { URB represented by the urbanization rate } \\
\text { of the permanent resident population. }\end{array}$ \\
\hline STR & Industrial structure & The primary industry output value divided by GDP & $\begin{array}{l}\text { STR is used to measure the degree of the } \\
\text { industrial structure optimization. }\end{array}$ \\
\hline $\mathrm{RD}(\mathrm{ED})$ & $\begin{array}{l}\text { Fiscal revenue } \\
\text { and expenditure } \\
\text { decentralization }\end{array}$ & $\begin{array}{l}\text { Provincial fiscal revenue (expenditure) within the provincial per } \\
\text { capita budget/(Provincial fiscal revenue (expenditure) within the } \\
\text { provincial per capita budget + fiscal revenue (expenditure) } \\
\text { within the central government's per capita budget) }\end{array}$ & $\begin{array}{l}\mathrm{RD}(\mathrm{ED}) \text { represents degree of fiscal } \\
\text { decentralization }\end{array}$ \\
\hline OPEN & Openness & The total import-export divided by GDP & $\begin{array}{l}\text { OPEN represents the degree of openness } \\
\text { to the outside world. }\end{array}$ \\
\hline
\end{tabular}

Table 2. Descriptive statistics

\begin{tabular}{llllll}
\hline Variables & Obs & Mean & S.D. & Min & Max \\
\hline POV & 189 & 11.053 & 8.756 & 0.200 & 45.100 \\
EDE & 189 & 4318.631 & 1378.324 & 1974.106 & 10791.550 \\
HEE & 189 & 178.631 & 52.201 & 81.074 & 399.390 \\
SOE & 189 & 550.255 & 175.787 & 163.386 & 973.952 \\
INFE & 189 & 1220.851 & 558.762 & 493.726 & 3117.879 \\
ENVE & 189 & 457.292 & 191.013 & 113.957 & 1147.925 \\
PGDP & 189 & 21399.210 & 7672.059 & 9380.182 & 40514.380 \\
URB & 189 & 0.460 & 0.082 & 0.215 & 0.604 \\
STR & 189 & 0.450 & 0.075 & 0.331 & 0.684 \\
RD & 189 & 52.059 & 8.335 & 33.810 & 69.200 \\
ED & 189 & 11.330 & 4.364 & 4.159 & 26.100 \\
OPEN & 189 & 0.217 & 0.226 & 0.029 & 1.227 \\
\hline
\end{tabular}

\section{Results and Discussion}

Before undertaking regression analysis, we first examined whether spatial autocorrelation exists in public expenditure and rural poverty. If the spatial autoregression coefficients $\rho$ pass the significance test at the $1 \%$ level and the estimated coefficients are positive, then spatial autoregression is present, signifying that the poverty of a given province is influenced by the poverty of its surrounding provinces. Models I-V in Table 3 present maximum likelihood estimates for the SAR model. The coefficients for the spatial lag term $\rho$ are positive and statistically significant at the $1 \%$ level in model I-V, showing a positive spatial agglomeration in rural poverty in China. 
We evaluate the spatial econometric models and selected the SAR that describes our data on the basis of the LM results. Using the Lagrange Multiplier Lag (LM-lag) and Lagrange Multiplier Error (LM-err) statistics (both significant at the $0.1 \%$ level), we tested the feasibility of the spatial lag panel data model and the spatial error panel data model (Anselin et al., 1996). The results of these tests showed that LM-lag and R-LM-lag are significant at the $1 \%$ level, while R-LM-error is nonsignificant. Therefore, the preliminary judgment is that SAR is the preferred model for this study. For the panel data set that covers 27 provinces and spans 7 years, the Hausman test is performed to choose between the fixed effect and random effect tests. And the results of a Hausman test showed that the fixed effect model was superior to the random (both $p$ values are 0 ). Thus, in the following discussion, we only refer to the SAR model with fixed effect estimates for different types of public expenditure variables reported in the tables.

Table 3 presents the results for the effect of rural public expenditure on poverty in China. Rural public expenditures are the core independent variables in model I-V, which represents EDE, HEE, SOE, INFE and ENVE as the core explanatory variables, respectively, which represent different types of rural public expenditure in China.

Table 3. Estimated results of spatial spillover effects of rural public expenditure on rural poverty (W)

\begin{tabular}{|c|c|c|c|c|c|}
\hline Model & Model I & Model II & Model III & Model IV & Model V \\
\hline LnEDE & $\begin{array}{l}-0.410 * * * \\
(-4.02)\end{array}$ & & & & \\
\hline LnHEE & & $\begin{array}{l}-0.668^{* * * *} \\
(-6.73)\end{array}$ & & & \\
\hline LnSOE & & & $\begin{array}{l}-0.183^{* * *} \\
(-3.48)\end{array}$ & & \\
\hline LnINFE & & & & $\begin{array}{l}-0.384 * * * \\
(-2.87)\end{array}$ & \\
\hline LnENVE & & & & & $\begin{array}{l}0.006 \\
(0.12)\end{array}$ \\
\hline LnPGDP & $\begin{array}{l}-0.910 * * * \\
(-3.08)\end{array}$ & $\begin{array}{l}-0.777 * * * \\
(-2.78)\end{array}$ & $\begin{array}{l}-1.165^{* * *} \\
(-3.75)\end{array}$ & $\begin{array}{l}-0.631 * * \\
(-2.01)\end{array}$ & $\begin{array}{l}-0.908 * * * \\
(-3.00)\end{array}$ \\
\hline LnURB & $\begin{array}{l}-0.096 \\
(-0.27)\end{array}$ & $\begin{array}{l}-0.571 \\
(-1.10)\end{array}$ & $\begin{array}{l}-0.061 \\
(-0.17)\end{array}$ & $\begin{array}{l}-0.152 \\
(-0.38)\end{array}$ & $\begin{array}{l}-0.493 \\
(-1.47)\end{array}$ \\
\hline LnSTR & $\begin{array}{l}0.121 \\
(0.95)\end{array}$ & $\begin{array}{l}0.106 \\
(0.92)\end{array}$ & $\begin{array}{l}1.165 \\
(0.68)\end{array}$ & $\begin{array}{l}0.025 \\
(0.20)\end{array}$ & $\begin{array}{l}0.059 \\
(0.47)\end{array}$ \\
\hline LnRD & $\begin{array}{l}-0.079 \\
(-0.50)\end{array}$ & $\begin{array}{l}-0.010 \\
(-0.07)\end{array}$ & $\begin{array}{l}-0.145 \\
(-0.92)\end{array}$ & $\begin{array}{l}-0.227 \\
(-1.46)\end{array}$ & $\begin{array}{l}-0.249 \\
(-0.12)\end{array}$ \\
\hline LnED & $\begin{array}{l}-1.104 * * \\
(-2.40)\end{array}$ & $\begin{array}{l}-1.462^{* * *} \\
(-3.45)\end{array}$ & $\begin{array}{l}-1.651 * * * \\
(-3.61)\end{array}$ & $\begin{array}{l}-1.102 * * \\
(-2.32)\end{array}$ & $\begin{array}{l}-1.491 * * * \\
(-3.18)\end{array}$ \\
\hline LnOPEN & $\begin{array}{l}0.046 \\
(0.87)\end{array}$ & $\begin{array}{l}0.024 \\
(0.48)\end{array}$ & $\begin{array}{l}0.028 \\
(0.50)\end{array}$ & $\begin{array}{l}0.030 \\
(0.53)\end{array}$ & $\begin{array}{l}0.078 \\
(1.45)\end{array}$ \\
\hline$\rho$ & $\begin{array}{l}0.856 * * * \\
(22.61)\end{array}$ & $\begin{array}{l}0.777 * * * \\
(16.01)\end{array}$ & $\begin{array}{l}0.853 * * * \\
(21.61)\end{array}$ & $\begin{array}{l}0.880 * * * \\
(25.66)\end{array}$ & $\begin{array}{l}0.893 * * * \\
(28.55)\end{array}$ \\
\hline Log-L & 65.428 & 81.914 & 63.479 & 61.359 & 57.166 \\
\hline R-sq & 0.148 & 0.232 & 0.281 & 0.224 & 0.275 \\
\hline AIC & -112.855 & -145.828 & -108.959 & -104.717 & -96.332 \\
\hline BIC & -83.680 & -116.652 & -79.783 & -75.541 & -67.156 \\
\hline
\end{tabular}

Note. The values in parentheses are the t-statistics corresponding to the respective estimated parameters; *, ** and $* * *$ indicate rejection of the null hypothesis at the $1 \%, 5 \%$ and $10 \%$ significance levels, respectively.

The SAR model results indicate that different public expenditures have different effects on poverty. which is consistent with theoretical expectations in Table 3. As shown in column 2-column 5 (model I-IV), the coefficients of public expenditure were significantly negative, indicating that EDE, HEE, SOE and INFE will improve rural poverty to certain extent in China. Specifically, when other variables are constant, a $1 \%$ increase of education expenditure, health expenditure, social security expenditure and infrastructure expenditure were found to be associated with a $0.410 \%, 0.668 \%, 0.183 \%$ and $0.384 \%$ decrease in poverty rate in China, 
respectively. While the coefficient of ENVE was insignificantly positive at the $10 \%$ significance level $(t=0.12)$, showing that living environment spending on poverty alleviation is uncertain.

These results indicated that public expenditures play important role in poverty alleviation. The reasons for the above results are as follows. Education is one of the guarantees in the "three guarantees" (Note 3) for poverty alleviation standards. Increasing education expenditure will directly help the poor improve their survivability, increase the level of personal income, and help directly reduce poverty (Gong et al., 2018). "Poverty due to illness, return to poverty due to illness" has always been an important cause of poverty. Increasing health expenditure can improve the health level in rural areas, meanwhile reduce the personal medical expenditure burden of the poor, extend the life span of labor groups, increase labor productivity, and thus reduce rural poverty. Most poor people can only rely on social security to have a direct impact on poverty reduction in poverty-stricken areas, especially deep areas, due to scarce resources and poor natural conditions. Increasing infrastructure spending can not only increase agricultural output in poor areas, but also provide temporary employment for the poor and achieve sustainable poverty alleviation. Living environmental expenditure accounts for a relatively low proportion of fiscal expenditure and is lower than other public expenditures, which may lead to limited poverty reduction effects of current living environment expenditures. Therefore, judging the impact of rural environment on poverty also needs to consider various external environmental factors and policies related to rural poverty reduction.

There is a large difference in the regression results of different types of rural public expenditures, while the regression results of the control variables in each model are little difference, as shown in Table 3 . The results of our estimation show that the regression coefficients of GDP per capita were significant at the $1 \%$ level in model I-V. This result suggests that increasing GDP per capita will lead to a decreased poverty rate. The poor can benefit from the "trickle-down effect" of economic growth and help improve rural poverty. Hence, accelerating economic growth helps poverty reduction (Kang, 2018; Liu et al., 2018). The coefficients of fiscal revenue decentralization were insignificantly positive at the $10 \%$ significance level for all model. Although China's tax jurisdiction and tax dominance have divided taxation into central tax, local tax, and central and local shared taxes in the reform of the tax-sharing system, the fiscal revenue authority is still mainly concentrated in the central government, which to some extent conceals the poverty reduction effect of fiscal revenue decentralization, resulting in an uncertain effect of income decentralization. The estimated coefficients of fiscal expenditure decentralization are positive, and all of them pass the tests at the $1 \%$ significance level in all model, which indicates that the fiscal expenditure decentralization play a significant positive role in poverty alleviation (Liu et al., 2018; Sanogo, 2019). Under the pressure of relatively limited tax revenue and the assessment of poverty alleviation performance, local governments have implemented social security policies that favor the poor, or increased people's livelihood fiscal expenditures such as rural health care, rural education, and rural infrastructure construction, so as to improve rural public service levels and thus reduce poverty. In addition, in terms of urbanization rate, structure industry and openness, the coefficients were insignificant for all models.

By further exploring spatial effects in the traditional panel data model, spatial effects can be further decomposed into direct effect, indirect effect (spillover effects), and total effect with reference to the research result of LeSage and Pace (2009). This research decomposes the impact on rural poverty in the SAR model into direct and indirect effects in Table 4. The results show that the estimated coefficients of independent variables' direct effect have the same direction with the estimated coefficients of the SAR model in Table 3, and the estimated coefficients and significance levels are also very close. 
Table 4. Direct effects, spatial spillover effects, and total effect decomposition of SAR models

\begin{tabular}{llll}
\hline Categories & Variables & Coefficient & t-statistics \\
\hline \multirow{4}{*}{ Direct effects } & LnEDE & $-0.635^{* * *}$ & -4.32 \\
& LnHEE & $-0.902^{* * *}$ & -8.24 \\
& LnSOE & $-0.280^{* * *}$ & -3.80 \\
& LnINFE & $-0.615^{* * *}$ & -3.01 \\
LnENVE & -0.011 & -0.13 \\
Indirect effects & LnEDE & $-2.226^{* * *}$ & -3.12 \\
& LnHEE & $-2.096^{* * *}$ & -4.39 \\
& LnSOE & $-0.959^{* * *}$ & -3.04 \\
LnINFE & $-2.356^{* *}$ & -2.52 \\
LnENVE & 0.048 & 0.13 \\
Total effects & LnEDE & $-2.861^{* * *}$ & -3.47 \\
& LnHEE & $-2.998^{* * *}$ & -5.72 \\
& LnSOE & $-1.240^{* * *}$ & -3.34 \\
& LnINFE & $-2.970^{* * *}$ & -2.69 \\
& LnENVE & 0.059 & 0.13
\end{tabular}

Note. ${ }^{*}, * *$ and $* * *$ indicate rejection of the null hypothesis at the $1 \%, 5 \%$ and $10 \%$ significance levels, respectively.

As shown in Table 4, it confirms the rationality of using the SAR model for exploring the spatial spillover of public expenditure. Specifically, $1 \%$ growth in EDE, HEE, SOE, INFE will directly decrease rural poverty by $0.635 \%, 0.902 \%, 0.280 \%$ and $0.615 \%$, respectively, and indirectly decrease rural poverty by $2.226 \%, 2.096 \%$, $0.959 \%$ and $2.356 \%$. Meanwhile, comparing the estimated coefficient of the direct effect and that of the indirect effect, it can be found that the negative spillover effects of the rural public expenditures are significantly greater than the direct scale effect. This indicates that the education expenditure, health expenditure, social security expenditure and infrastructure expenditure not only promote poverty reduction in the region but also reduce poverty in economically and geographically similar areas. This is mainly because areas with relatively high government spending tend to be concentrated in developed areas in China. These areas with higher government spending have a major influence on neighboring areas, promoting economic development and reducing poverty. For areas with relatively low rural public expenditure and economic development is relatively lagging, there will be corresponding agglomeration, such as China's "three states and three districts" and other deep poverty areas, which are restricted by geographical location, natural conditions and other factors.

\section{Conclusion}

This paper analyses the effect of rural government spending on poverty in 27 provinces of China for 2010-2016, taking into consideration five dimensions: EDE, HEE, SOE, INFE and EVNE. It also estimated structural differences in poverty reduction effects of rural public expenditure using the SAR model and distinguished between the direct and indirect impacts of rural public expenditure on rural poverty. The main conclusions that can be drawn from our results are as follows.

This paper establishes the structural differences in poverty reduction effects of government spending are very obvious. Specifically, the poverty reduction effects of the five rural public expenditures of education, health care, social security, infrastructure, living environment are not consistent. At the national level, expenditures on education, health care, social security and infrastructure have all shown good poverty alleviation effects, while living environment spending has no significant effect on poverty reduction. In terms of the implications for policy, the key issue is how the contribution of government spending to the reduction of poverty can be strengthened. The government can make necessary adjustments to the structure of public expenditure based on whether various public expenditures have produced significant poverty reduction effects. For example, continue to increase spending on education, health care, social security, and infrastructure to increase its poverty reduction effect. At the same time, improve external conditions, such as increasing investment in living environment, promoting the improvement of rural human settlements and developing emerging green services.

This paper also estimated the spatial spillover effects to be quite different in relation to different rural government spending and rural poverty. This indicates that the education expenditure, health expenditure, social security expenditure and infrastructure expenditure not only promote poverty reduction in the region, but also 
reduce poverty in economically and geographically similar areas. While poverty reduction effect on living environment expenditure is not significant for the area and economically and geographically similar areas. Future work should look more closely at whether and how the effect of government spending on poverty varies by region. We propose to start with the overall situation, and actively use the space spillover effects of public expenditure to reduce poverty through policy coordination and action coordination between regions, and solve the problem of regional poverty.

\section{References}

Anderson, E., d'Orey, M. A. J., Duvendack, M., \& Esposito, L. (2018). Does Government Spending Affect Income Poverty? A Meta-regression Analysis. World Development, 103, 60-71. https://doi.org/10.1016/ j.worlddev.2017.10.006

Anselin, L. (1993). The Moran Scatterplot as an ESDA Tool to Assess Local Instability in Spatial Association. Regional Research Institute, West Virginia University Morgantown, WV.

Anselin, L., Bera, A. K., Florax, R., \&Yoon, M. J. (1996). Simple diagnostic tests for spatial dependence. Reg. Sci. Urban Economic, 26(1), 77-104. https://doi.org/10.1016/0166-0462(95)02111-6

Asadullah, M. N., Savoia, A., \& Mahmud, W. (2014). Paths to Development: Is there a Bangladesh Surprise? World Development, 62, 138-154. https://doi.org/10.1016/j.worlddev.2014.05.013

Asghar, N., Azim, P., \& Rehman, H. (2011). Impact of Government Spending in Social Sectors on Economic Growth: A Case Study of Pakistan. Journal of Business \& Economics, 3(2), 214-234.

Asghar, N., Hussain, Z., \& Rehman, H. U. (2012). The Impact of Government Spending on Poverty Reduction: Evidence from Pakistan 1972 to 2008. African Journal of Business Management, 6(3), 845-853. https://doi.org/10.5897/AJBM11.922

Benjamin, D., Sudhanshu, H., \& Maria R. A. (2005). Agricultural Subsidies, Human Capital Development and Poverty Reduction: Evidence, from Rural Mexzco. Inter-American Development Bank, Washington, D.C.

Conchada, M. L. P., \& Rivera, J. P. R. (2013). Assessing the Impacts of Food and Non-Food Grants on Poverty Alleviation in the Philippines: The Case of Pasay City. Malaysian Journal of Economic Studies, 50, 53-78.

Canale, R. R., Liottib, G., \& Marani, U. (2019). Structural public balance adjustment and poverty in Europe. Structural Change and Economic Dynamics, 50, 227-236. https://doi.org/10.1016/j.strueco.2019.07.002

Chu, M. K., Davoodi, H. R., \& Gupta, S. (2000). Income distribution and tax and government social spending policies in developing countries. International Monetary Fund. https://doi.org/10.5089/9781451848281.001

Cox, D., Hansen, D., \& Jimenez, E. (2004). How responsive are private transfers to income? Evidence from a laissez-faire economy. Journal of Public Economics, 88(9-10), 2193-2219. https://doi.org/10.1016/S00472727(03)00069-0

Deng, H. L., Huang T. Y., \& Xin, N. (2015). Spatial Spillover and Threshold Characteristics of Poverty Reduction Effect of the Fiscal Expenditure on Education: Analysis on the Panel Data in Jiangxi Province from 2001 to 2010. Education Research Monthly, 9, 50-61. https://doi.org/10.16477/j.cnki.issn1674-2311. 2015.09.007

Duan, L. L., \& Wang, L. M. (2018). Who is Better for Rural Poverty Reduction Fiscal Support Agriculture or Urbanization. Journal of Guizhou University of Finance and Economics, 5(196), 86-95.

Easterly, W., \& Fischer, S. (2001). Inflation and the poor. Journal of Money. Credit and Banking, 33(2), 160-178. https://doi.org/10.2307/2673879

Elhorst, J. P. (2003). Specification and estimation of spatial panel data models. Int. Reg. Sci. Rev., 3, 244-268. https://doi.org/10.1177/0160017603253791

Fan, S. G., Brzeska, J., \& Shields, G. (2007). Investment Priorities for Economic Growth and Poverty Reduction. International Food Policy Research Institute (IFPRI).

Fan, S. G., Chan-Kang, C., Qian, K. M., \& Krishnaiah, K. (2005). National and International Agricultural Research and Rural Poverty: The Case of Rice Research in India and China. Agricultural Economics, 33(3), 369-379. https://doi.org/10.1111/j.1574-0864.2005.00077.x

Fan, S. G., Zhang, L., \& Zhang, X. B. (2002). Growth, Inequality, and Poverty in Rural China: The Role of Public Investments. Washington, D.C.: International Food Policy Research Institute. 
Gaiha, R., \& Imai, K. (2002). Rural Public Works and Poverty Alleviation-the Case of the Employment Guarantee Scheme in Maharashtra. International Review of Applied Economics, 16, 131-151. https://doi.org/10.1080/02692170110118876

Gittell, R. (2010). The wider impacts of BRAC poverty comparative perspectives on the relationship of public finance and poverty. Public Finance and Management, 10(6), 405-410.

Gomanee, K., \& Morrissey, O. (2002). Evaluating Aid Effectiveness against a Poverty Reduction Criterion. DESG Conference, Nottingham.

Gong, W. J., Qin, C. L., \& Li, C. (2018). Poverty Alleviation Effect of China's Fiscal Expenditure-Based on Structure and Space. Research on Economics and Management, 39(5), 24-37. https://doi.org/10.13502/ j.cnki.issn1000-7636.2018.05.003

Harrison, J. L., Montgomery, C. A., \& Jeanty, P. W. (2019). A spatial, simultaneous model of social capital and poverty. Journal of Behavioral and Experimental Economics, 78, 183-192. https://doi.org/10.1016/j.socec. 2018.09.001

Inoue, T. (2018). Financial development, remittances, and poverty reduction: Empirical evidence from a macroeconomic viewpoint. Journal of Economics and Business, 96, 59-68. https://doi.org/10.1016/ j.jeconbus.2017.12.001

Kang, M. M. (2018). Regional Difference of Poverty Alleviation Effect of China's Insurance Industry and Threshold Characteristics: An Empirical Study Based on the Provincial Panel Data. Insurance Studies, 7, 30-44. https://doi.org/10.13497/j.cnki.is.2018.07.004

Kruse, I., Pradhan, M., \& Sparrow, R. (2012). Marginal Benefit Incidence of Public Health Spending: Evidence from Indonesian Sub-national Data. Journal of Health Economics, 31(1), 147-157. https://doi.org/10.1016/ j.jhealeco.2011.09.003

Lal, D., \& Sharma, A. (2009). Private Household Transfers and Poverty Alleviation in Rural India: 1998-99. The Journal of applied Economic Research, 32, 97-112. https://doi.org/10.1177/097380100900300201

Leng, Z., Huang, J. M., \& Zhong, Z. P. (2016). Study on Regional Differences of Supply Efficiency of Rural Public Goods in China. Agricultural Technology Economy, 5, 80-91. https://doi.org/10.13246/j.cnki.jae. 2016.05.009

LeSage, J. P., \& Pace, R. K. (2009). Introduction of Spatial Econometrics (p. 8). Boca Raton, CRC Press. https://doi.org/10.1201/9781420064254

Lindert, K., Skoufias, E., \& Shapiro, J. (2006). Redistributing income to the poor and the rich: Public transfers in Latin America and the Caribbean. Social Safety Nets Primer Series.

Liu, H. Y., \& Zhang, C. H. (2011). Comparative Study on the Input-Output Dynamic Efficiency of China's Urban and Rural Health Economy System. Agricultural Economic Issues, 2, 44-51.

Liu, J. M., Ou-Yang, L., \& Mao, J. (2018). Fiscal Decentralization, Economic Growth and Government Poverty Reduction. Chinese Soft Science, 6, 139-150.

Liu, Y., \& Lin, W. L. (2014). Analysis of Present Situation of Basic Public Service in China. Journal of Northwest A\&F University (Social Science Edition), 14(2), 134-139. https://doi.org/10.13968/j.cnki.10099107.2014.02.002

Lustig, N. (2019). Book review of Commitment to Equity Handbook, Estimating the Impact of Fiscal Policy on Inequality and Poverty. The Journal of Economic Inequality, 17, 439-442. https://doi.org/10.1007/s10888019-09417-7

NBS (National Bureau of Statistics). (2020). The 2019 National Economic and Social Development Statistical Bulletin.

Olopade, B. C., Okodua, H., Oladosun, M., \& Asaleye, A. J. (2019). Human capital and poverty reduction in OPEC member-countries. Heliyon, 5. https://doi.org/10.1016/j.heliyon.2019.e02279

Oluwatobi, S. O., \& Ogunrinola, I. O. (2011). Government Expenditure on Human Capital Development: Implications for Economic Growth in Nigeria. Journal of Sustainable Development, 4(3), 72. https://doi.org/10.5539/jsd.v4n3p72

Qiu, X. J., \& Wen, Z. H. (2012). Analysis on the Efficiency of Chinese Rural Social Security Fiscal Expenditures. Economic Issues, 3, 74-78. https://doi.org/10.16011/j.cnki.jjwt.2012.03.022 
Ravallion, M. (2012). Why don't we see poverty convergence? American Economic Review, 102(1), 504-523. https://doi.org/10.1257/aer.102.1.504

Sahn, D. E., \& Alderman, H. (1996). The effect of food subsidies on labor supply in SriLanka. Economic Development and Cultural Change, 45(1), 125-145. https://doi.org/10.1086/452260

Sanogo, T. (2019). Does fiscal decentralization enhance citizens' access to public services and reduce poverty? Evidence from Côte d'Ivoire municipalities in a conflict setting. World Development, 113, 204-221. https://doi.org/10.1016/j.worlddev.2018.09.008

Sergiy, Z. (2006). Improving agricultural fiscal policy in Ukraine (Working Paper, pp. 1-36).

Son, H., \& Kakwani, N. (2008). Global estimates of pro-poor growth. World Development, 36(6), 1048-1066. https://doi.org/10.1016/j.worlddev.2007.10.002

Tang, J. L. (2016). Evaluation on Supply Level of Rural Public Goods in China. Technology Economics, 1(35), 92-96.

Verschoor, A., \& Kalwij, A. (2006). Aid, social policies and pro-poor growth. Journal of International Development, 18, 519-530. https://doi.org/10.1002/jid.1248

Wang, Y. M., \& Liu, Z. H. (2016). Evaluating the Policy Effect of Large-Scale Public Expenditure Projects: Taking "Seven-Year Priority Poverty Alleviation Program" as an Example. Finance \& Trade Economics, 37(1), 33-47. https://doi.org/10.19795/j.cnki.cn11-1166/f.2016.01.004

Wardhana, D., Ihle, R., \& Heijman, W. (2017). Agro-clusters and Rural Poverty: A Spatial Perspective for West Java. Bulletin of Indonesian Economic Studies, 53(2), 161-186. https://doi.org/10.1080/00074918. 2017.1298722

Westmore, B. (2018). Do government transfers reduce poverty in China? Micro evidence from five regions. China Economic Review, 51, 59-69. https://doi.org/10.1016/j.chieco.2018.05.009

Yu, Y., Zhang, L., Li, F., \& Zheng, X. (2011). On the Determinants of Public Infrastructure Spending in Chinese Cities: A Spatial Econometric Perspective. The Social Science Journal, 48(3), 458-467. https://doi.org/ 10.1016/j.soscij.2011.05.006

Zeng, F. S., \& Zeng, X. X. (2013). Empirical Study on Poverty Reduction in Basic Public Services: A Case Study of Hunan Province. Agricultural Technology Economy, 8, 4-11. https://doi.org/10.13246/j.cnki.jae. 2013.08.005

Zou, W. J. (2014). Poverty Reduction Effects and Threshold Features of Equalization of Medical and Health Services: An Analysis Based on Spatial Heterogeneity. Economist, 8, 59-65. https://doi.org/10.16158/ j.cnki.51-1312/f.2014.08.020

Zuo, T., Xu, J. Y., \& Li, Z. (2018). Shaking off Difficulties in Poverty: Basic Public Service Approach to Poverty Alleviation in Severely Poor Areas in China. Journal of Nanjing Agricultural University (Social Sciences Edition), 18(2), 35-44.

\section{Notes}

Note 1. Since Beijing, Tianjin, and Shanghai are developed regions with high degree of urbanization and almost no poor people, and the yearbook shows that poverty rate is small or zero in these areas, the above three regions are excluded.

Note 2. Because the Urban and Rural Construction Statistical Yearbook uses the registered population and the number of temporary residents as the statistical caliber, and the corresponding data is based on the data of the local public security department, the user population and the temporary population to eliminate the impact of population size.

Note 3. "Three guarantees" means compulsory education, basic medical care, and housing safety are guaranteed.

\section{Copyrights}

Copyright for this article is retained by the author(s), with first publication rights granted to the journal.

This is an open-access article distributed under the terms and conditions of the Creative Commons Attribution license (http://creativecommons.org/licenses/by/4.0/). 